\title{
Factors that Contribute to Domestic Waste Recycling: A Preliminary Survey
}

\author{
Hamizah Yakob1, Nurul Rif'ah Afiqah Abd Rauf², Yusfida Ayu Abdullah³, Oliver Ling Hoon Leh4 \\ 1,3,4 Centre of Studies for Town and Regional, Faculty of Architecture, Planning and Surveying, \\ Universiti Teknologi MARA, Puncak Alam Campus, Malaysia. \\ ${ }^{2}$ Centre of Postgraduate Studies, Faculty of Architecture, Planning and Surveying, \\ Universiti Teknologi MARA, Shah Alam, Selangor, Malaysia.
}

hamizah1204@gmail.com, nurulrifahafiqah@gmail.com, ayunazeri@gmail.com, oliver3979@uitm.edu.my Tel: 012-2221768

\begin{abstract}
It is undeniable that household recycling was studied extensively. Nonetheless, the recycling behaviour of householders living in urban areas has received less attention including in Malaysia. Therefore, the objective of this preliminary study is to outline the perception of factors that drive humans to recycle domestic waste among urban households. The study conducts a site investigation and questionnaire survey in six (6) suburbs of Shah Alam by using a Convenience Sampling method. The outcomes are influenced by not only the factors in recycling but human attitudes and behaviours, which reflect their contribution towards waste generation and domestic waste recycling practice.
\end{abstract}

Keywords: Human Behaviour; Domestic Waste Recycling; Waste Generation; Urban Households

eISSN: 2398-4287@ 2020. The Authors. Published for AMER ABRA cE-Bs by e-International Publishing House, Ltd., UK. This is an open access article under the CC BYNC-ND license (http://creativecommons.org/licenses/by-nc-nd/4.0/). Peer-review under responsibility of AMER (Association of Malaysian Environment-Behaviour Researchers), ABRA (Association of Behavioural Researchers on Asians) and cE-Bs (Centre for Environment-Behaviour Studies), Faculty of Architecture, Planning \& Surveying, Universiti Teknologi MARA, Malaysia. DOI: https://doi.org/10.21834/ebpj.v5i15.2489.

\section{Introduction}

Malaysia is experiencing the global issues of waste management, scarcity of land for landfill, weaknesses in recycling management and enforcement, lack of the 3R hierarchy practice, pollution and rising cost of waste management (Behzad, Ahmad, Saied, Elmira \& Bin, 2011). There was also an absence of mechanism and studies focusing on domestic waste for recycling. Separating domestic waste into recyclable items can reduce the mass amount of waste mostly generated from households. It classifies waste reduction based on the ability to reduce waste such as unwanted clothes, electronic and gadgets, furniture, newspaper, bottles and metals. There were many issues related to waste disposal management and particularly mechanism to recycling such as the belief of being sustainable but unfortunately not the practice. The idea of environmental sustainability is linked with "nature and technology" but people behaviours did not indicate their interest in environmental sustainability (Tolinski, 2012). Many may not realise that household goods can be recycled. Yet, up to this day, waste disposal management issues continue. Mokhtar (2016) shared the disturbing statistics with regards to waste management showing an increased volume of waste collected each day. This situation leads to scarcity of land for landfill and leads to the rising cost of waste management. Other than that, Malaysia is far from being successful in terms of recycling activities as compared to other developing countries with higher recycling rate such as German, Taiwan, Sweden and Singapore. Additionally, (Shahol Hamid, \& Agamuthu, 2012) claimed that the public's practice of the Global 3Rs approach is still lacking. Several studies discovered the same issues of the lack of recycling (Ahmad, Ahmad and Tahir, 2017; Jereme, Siwar and Mahmudul Alam, 2015; Wee and Mat Radzuan,

eISSN: 2398-4287C 2020. The Authors. Published for AMER ABRA cE-Bs by e-International Publishing House, Ltd., UK. This is an open access article under the CC BYNC-ND license (http://creativecommons.org/licenses/by-nc-nd/4.0/). Peer-review under responsibility of AMER (Association of Malaysian Environment-Behaviour Researchers), ABRA (Association of Behavioural Researchers on Asians) and cE-Bs (Centre for Environment-Behaviour Studies), Faculty of Architecture, Planning \& Surveying, Universiti Teknologi MARA, Malaysia.

DOI: https://doi.org/10.21834/ebpj.v5i15.2489. 
2010). On that count, the aim for this preliminary study is therefore to investigate household's understanding of attitudes and behaviours which reflects their contribution towards domestic waste recycling practice. This paper looks forward to appraising the theory of human behaviour towards the urban environment, its factors and examine the household's practice and mechanism towards domestic waste recycling. Also, this study constructs the theory of recycling framework that relates to the human behaviours among urban households. Using the hypothesis that household behaviours are more inclined to domestic recycling, this study conducts a questionnaire survey in six suburbs of Shah Alam as a case study. The research was conducted by focusing on factors that drive households to recycle domestic waste and households recycling behaviours influenced by the type of accommodation and occupation sector concerning the practice of domestic waste recycling.

\subsection{Literature Review}

\subsection{Concept of Recycling}

According to Othman \& Yuhaniz, (2012), recycling is a process - a series of activities that include the collection and sorting of waste materials, the processing of these materials to produce brand new products and the purchase and use of these new products by consumers. Kawasaki (2014) stated domestic waste which is known as kitchen waste or household waste, is unused household waste. Consists of non-hazardous waste and hazardous waste, this study enlightens the non-hazardous waste such as food waste, paper, box, furniture, e-waste, textiles, plastic and glass. Abas, (2014) claimed it as any product separated into organic and inorganic waste. Organic waste consists of food waste, garden waste, paper, clothing, and rubber waste. The inorganic waste consists of chemical waste, metal and glass waste. The key goal of waste management is to reduce the volume of waste that is disposed of in landfills. Hence, the basic 3R (Reduce, Reuse, Recycle) principle encourages collaboration between waste producers, waste collectors, processors and manufacturers to minimize the amount of waste to be disposed of in landfill sites, thus reducing the pollution generated by landfill sites and saving energy and natural resources (Umar, Sehab, \& Yagnik, 2018). In Malaysia, government has implemented vary recycling programs and approaches in order to make recycling as an easy option. For example, the provision of recycling facilities such as recycling bins, placed them strategically next to trash cans in parks, parking lots and plazas. Recyclable goods, facilities and services must be regulated daily to prevent overflowing and increase people's courage to recycle (Zen, Noor, \& Yusuf, 2014).

\subsection{Theory of Planned Behaviour (TPB) Framework}

The literature on recycling behaviour focuses largely on psychological factors such as attitudes and social norms (Thomas \& Sharp, 2013). Despite the existence of numerous behavioural theories, Theory of Planned Behaviour (TPB) is the most commonly applied theory to explain the pro-environmental intention and behaviour (Al Mamun, Mohiuddin, Ahmad, Thurasamy, \& Fazal, 2018) and has been applied by many researchers in a diverse area such as health, education, consumer behaviour, environment and technology studies (Kumar, 2019). The TPB emphasize that behaviour refers to a willingness to avoid or perform a certain task, in this case as performing domestic waste recycling (i.e., intention) and the control an individual perceives he or she has over a concerning behaviour (i.e., perceived behaviour control (PBC). According to the TPB, from earlier to recent study by Ajzen (1985,1991), (Chu \& Chiu, 2003), (Miafodzyeva, 2012), (Xu, Ling, Lu, \& Shen, 2017), (Strydom, 2018),(Kumar, 2019) and (Wang, Ren, Dong, Zhang, \& Wang, 2019), human actions are driven by three (3) kinds of belief. First, is about the possible outcome of specific behaviour and the evaluations of such outcome (behavioural belief). Secondly is concerned with normative expectation of others significant and motivation to comply with such expectation (normative beliefs) and thirdly is concerned the absence or presence of other factors that may disrupt the performance of behaviour along with perceived power such as factors (control beliefs). An individual's capability of a certain behaviour is determined by the individual's intent to perform that behaviour. Attitudes are informed by beliefs; norms are informed by normative beliefs and motivation to comply, and perceived behaviour control is informed by beliefs about individual's possession of the opportunities and resources needed to engage in the behaviour (Miafodzyeva, 2012). Generally, the more knowledge about recycling and its impact on the natural world, the more likely it is that a household will practices.

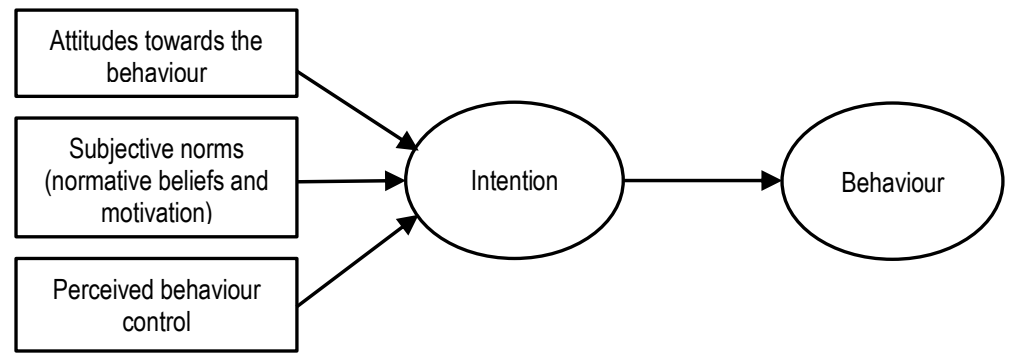

Fig. 1: A basic model of TPB Framework adopted from Ajzen (1991)

(Source: Ajzen (1985,1991), Chu \& Chiu, (2003), Miafodzyeva, (2012), Xu, Ling, Lu, \& Shen, (2017), Strydom, (2018), Kumar, (2019) and Wang, Ren, Dong, Zhang, \& Wang, (2019) 


\subsection{Extended TPB Framework - Factors of Recycling Behaviour}

In the context of recycling, diverse behaviours have been explained using extended TPB model with the addition constructs variable such as policy regulation, incentives, facilitating condition, subject norm, moral norm, self-efficacy and awareness of consequences (Knickmeyer, 2020). A person's attitude toward targeted behaviour begins by experience, understanding, knowledge and conception about a certain behaviour. As a result, attitude can be determined by various factors. Ong, Fearnley and Chia (2019) studied that there were five factors to measures the structure of variables. There are behavioural measures, social-psychological measures, knowledge of recycling measures, social structural measures and situational factors. A study by Miliute-Plepiene, Hage, Plepys, \& Reipas, (2016) identified four types of factors shaping household recycling behaviour which are socio-psychological, techno-organisational, sociodemographic and other study-specific factors. Hence, this study has determined the extended research model of TPB framework to be used as basis variables to measure the urban household's behaviour. These five factors were chosen in measuring factors pertaining issues and problem of domestic waste recycling practice.

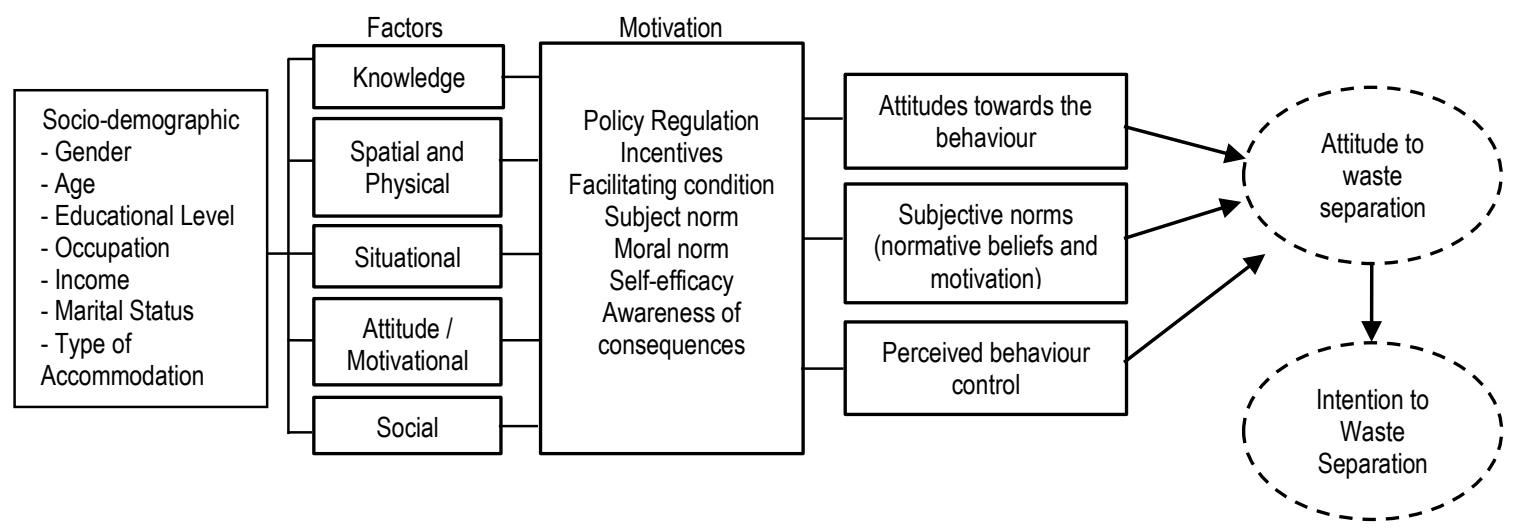

Fig. 2: Extended research model of TPB Framework

(Source: Ajzen (1985,1991), Chu \& Chiu, (2003), Miafodzyeva, (2012), Miliute-Plepiene et al., (2016), Xu, Ling, Lu, \& Shen, (2017), Strydom, (2018), Kumar, (2019), Wang, Ren, Dong, Zhang, \& Wang, (2019), and Ong et al., (2019)

\subsection{Methodology}

The research undertakes primary data collection using a household questionnaire survey. This preliminary survey was conducted in Shah Alam, Selangor densely involved six (6) suburbs areas which are Seksyen 2, 6, 7, 8, 10 and 11. The study area is one of the significant as the highest urban populated state. Shah Alam City Council (MBSA) had implemented various programmes and initiatives to ensure that the city was kept clean and well maintained thus to educate the local population on the importance of recycling. The criteria for site selection are basically on reclamation title as "Projek Zon Bersih". MBSA has located recycling centre at Seksyen 2, 6, 7 and 11 which has been one of the prominent areas to evaluate the household behaviour towards domestic waste recycling. The neighbourhoods chosen are those of landed and high rise property comprises of low cost, medium and high-cost houses. The sample size determined for the preliminary survey is 100 respondents, however, due to constraints in term of respondent's willingness to take part in the survey and also due to unoccupied units during data collection, the survey managed to get only ninety samples of respondents using a convenience sampling method. The survey was conducted in three days; Friday, Saturday and Sunday (in September 2020) started at 8 a.m. until 7 p.m. each day. The questionnaire samples distributed to each selected Seksyen accordingly and the first unit of the housing block is randomly chosen. If there is a vacant and unwilling household to participate in the survey, the questionnaire is still distributed to the next houses.

Table 1. Theory Planned Behaviour Factors and related variables to measure

\begin{tabular}{lc}
\hline TPB Factors & Variables \\
\hline Knowledge & Level on knowledge about natural environmental \\
Spatial and Physical & Awareness of waste management \\
Situational & Individual commitment to recycling \\
Attitude / Motivational & Quality of recycling facilies locion, access and collection \\
Social & Social responsible, rules and regulations, incentives and rewards \\
\hline (Source: Miliute-Plepiene et al., (2016), Kumar, (2019), Wang, Ren, Dong, Zhang, \& Wang, (2019), and Ong et al., (2019))
\end{tabular}

Measurement on household recycling behaviour can be obtained using five measures mentioned in Table 1 to derive the factors that constituted behavioural measure. First, behavioural measures that constructed three (3) scales namely as variety recycling scale or other study-specific factors. Second, frequent recyclers indicate how often an individual prepares or separates household domestic waste for recycling. Third, variety reuse scale refers to a similar set of household items and materials which imply that items are neither sold, donated nor discarded into waste stream or roadside. Next, social-psychological measures social pressure in terms of (dis)approval from others (friends, neighbours and relatives), awareness, rules and regulation (Miliute-Plepiene et al., 2016). Third, knowledge of recycling measures by understanding the household's level of knowledge and awareness of what materials are appropriate for recycling. Besides, social structural measures as determined by Ong et al., (2019) and socio-demographic factors stated by Miliute-Plepiene et 
al., (2016) which similar variables to measures such as age, education, household income, gender, occupation and type of accommodation. Lastly, situational factors which included a measure of the quality of recycling infrastructures, location of collection bins and frequency of collection, attractiveness of collection points and ease of the recycling process. The data gathered were statistically analysed using SPSS. Mean score was used to analyse the data and Mann Whitney U Test analysis is carried out to measure correlation between those living in landed and high rise houses.

\subsection{Findings}

\subsection{Residents Demographic Profile}

Most landed households and high rise respondents $(\mathrm{N}=90)$ were female $(55.6 \%)$. About $61 \%$ of the respondents have income less than RM4849 with $30 \%$ of them were employed as Professional. Most of respondents have Bachelor Degree and Diploma with $43.3 \%$ and $36.7 \%$ respectively. Regarding age, both groups of respondents were mostly aged between 18 to 35 years old (57.8\%).

Table 2. Respondent's demographic profile

\begin{tabular}{|c|c|c|c|c|c|}
\hline \multirow[t]{2}{*}{ Variables } & \multirow[t]{2}{*}{ Categories } & \multicolumn{2}{|c|}{ Type of Accommodation } & \multirow{2}{*}{$\begin{array}{c}\text { Frequency } \\
\mathrm{N}=90\end{array}$} & \multirow[t]{2}{*}{$\%$} \\
\hline & & Landed & High rise & & \\
\hline \multirow[t]{2}{*}{ Gender } & Male & 27 & 13 & 40 & 44.4 \\
\hline & Female & 32 & 18 & 50 & 55.6 \\
\hline \multirow[t]{5}{*}{ Age } & $13-17$ years & 1 & 1 & 2 & 2.2 \\
\hline & $18-35$ years & 33 & 19 & 52 & 57.8 \\
\hline & $36-45$ years & 14 & 7 & 21 & 23.3 \\
\hline & $46-55$ years & 9 & 2 & 11 & 12.2 \\
\hline & $>56$ years & 2 & 2 & 4 & 4.4 \\
\hline \multirow[t]{5}{*}{ Education level } & Certificate & 7 & 8 & 15 & 16.7 \\
\hline & Diploma & 18 & 15 & 33 & 36.7 \\
\hline & Bachelors & 322 & 7 & 39 & 43.3 \\
\hline & Master & 2 & 1 & 3 & 3.3 \\
\hline & $\mathrm{PhD}$ & - & - & - & - \\
\hline Household & $<\mathrm{RM} 4,849$ & 29 & 26 & 55 & 61.1 \\
\hline \multirow[t]{2}{*}{ Income } & RM4,850-RM10,959 & 26 & 5 & 31 & 34.4 \\
\hline & $>\mathrm{RM} 10,960$ & 4 & 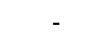 & 4 & 4.4 \\
\hline \multirow{2}{*}{ Marital Status } & Single & 16 & 8 & 24 & 26.7 \\
\hline & Married & 43 & 23 & 66 & 73.3 \\
\hline \multirow[t]{6}{*}{ Occupation } & Professional & 21 & 6 & 27 & 30.0 \\
\hline & Technicians & 11 & 3 & 14 & 15.6 \\
\hline & Clerical Workers & 7 & 6 & 13 & 14.4 \\
\hline & Services and Sales & 10 & 5 & 15 & 16.7 \\
\hline & Machine Operator & - & 3 & 3 & 3.3 \\
\hline & Unemployed (Housewife \& Students) & 10 & 8 & 18 & 20.0 \\
\hline Type of & Landed Property & 59 & - & 59 & 65.6 \\
\hline Accommodation & High rise Property & - & 31 & 31 & 34.4 \\
\hline
\end{tabular}

\subsection{Approaches on Separating Domestic Waste}

The result indicates respondents living in landed properties $(n=18, N=90)$ prefer to handle and isolate their domestic waste, but not all send their domestic waste to recycling centres $(n=24, N=90)$. There are still those who segregate domestic waste and put it in their bins and public bins to be managed by the council. Similar to those living in high-rise property, it does not prevent them from doing recycling activities. However, there are a few respondents from both groups claimed that many more would partake in this activity if there are parties that provide public bins and collect from block to block since some of them cannot go to the recycling centre especially for high-rise residents and distant home to the recycling centre.

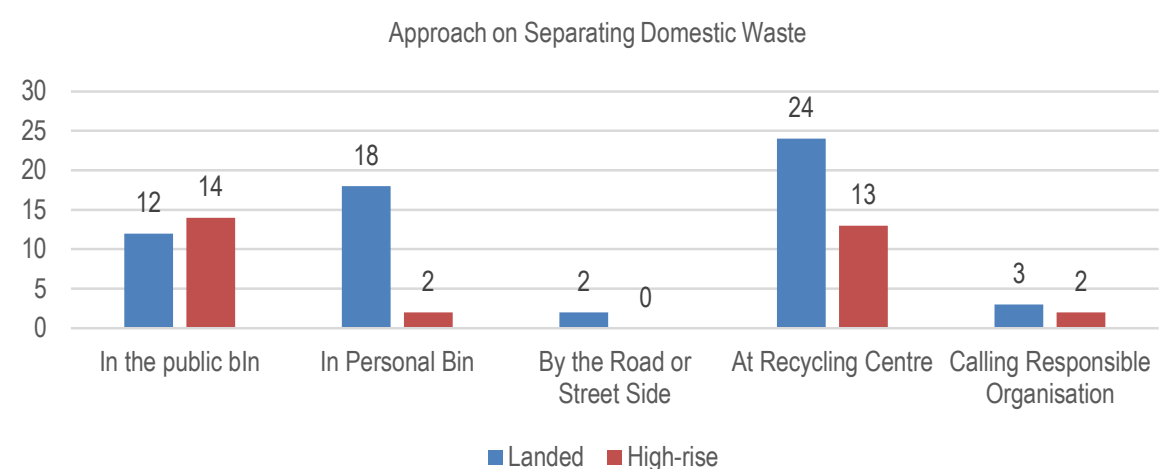

Fig. 3: Approaches on separating domestic waste among landed and high-rise residents 


\subsection{Problems on Managing Domestic Waste according to Occupation}

Most of them did not encounter any problems with recycling their domestic waste because they intended to do so and the facilities provided by the council facilitated their affairs. However, a few respondents believe that recycling is difficult for them in terms of their time management and distance from houses to recycling facilities. The researcher asked several questions about the issues they encountered during recycling activity. Due to their job considerations, some respondents claimed time constraints caused difficulty for them to isolate and conduct recycling activities as a daily basis. However, most of unemployed respondents (housewife and students) have no difficulties in managing domestic waste recycling. It showed unemployed individuals have more time to structure their household and conduct recycling activities.

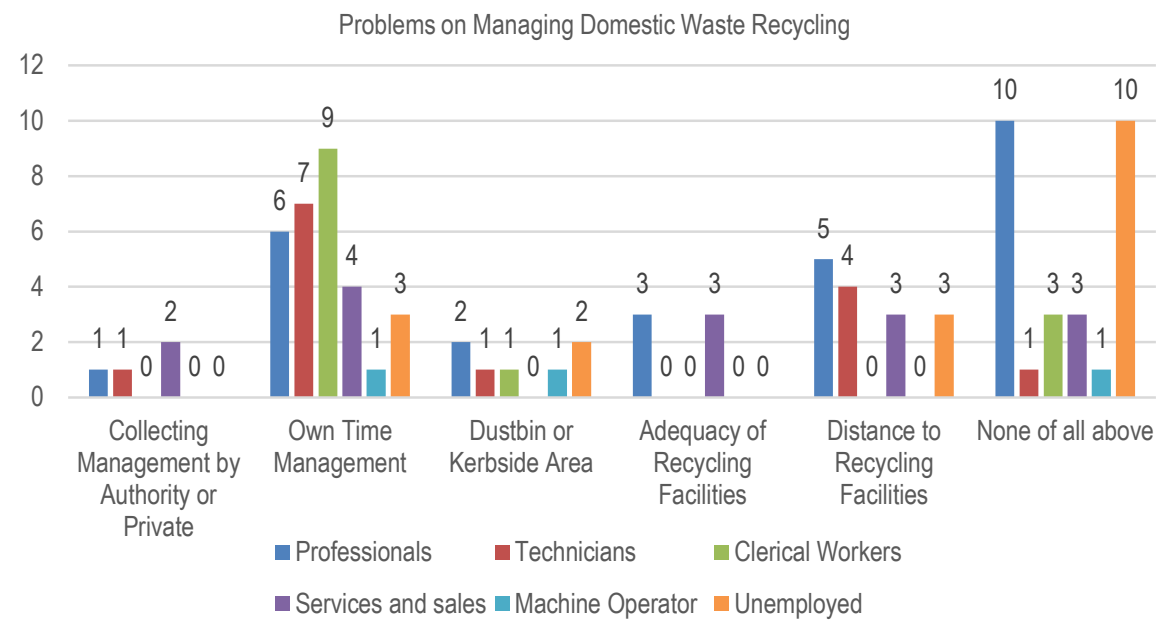

Fig. 4: Problems on managing domestic waste recycling according to type of occupation among urban households.

\subsection{Factor Analysis on Domestic Waste Recycling between Landed and High rise urban household}

Table 3 shows the summary statistic of Mann Whitney U Test of five factors. There was a significant difference in spatial and physical factor (2 variables) and situational factor (1 variable) between landed and high rise households. For spatial and physical factor, there is significant difference $(p<0.05)$ in perception on less provision of dustbin $(p=0.001)$ between both groups of respondents. Specifically, respondent staying at landed property ranked first (mean rank $=51.9$ ) and followed by those staying in high rise property (mean rank $=33.3$ ). Secondly, there is significant difference in perception of no access for responsible organisation to collect recyclable $(p=0.022)$. Similarly, those staying in landed property ranked first (mean rank $=49.9$ ) and followed by respondent staying at high rise property (mean rank $=37.05$ ). Furthermore, for situational factor, the result show issue on lack of access to recycling facilities differs between both groups of respondents $(p=0.03$ ). Specifically, respondent staying at landed property ranked first (mean rank $=49.6)$, followed by those staying in high rise property (mean rank $=37.5)$. However, the result also shows there are no significant differences at all $(p>0.05)$ in the perception on the knowledge ( 5 variables), attitude ( 6 variables) and social ( 5 variables) between both groups of respondents. Based on mean score, knowledge ( 5 variables), situational (4 variables), attitude (3 variables) and social (4 variables) between both groups of respondents are below scale of 3 . This indicates that respondents were agreed with issues highlighted based on factors above.

Table 3: Mean Rank and p-value of Knowledge, Spatial and Situational

\begin{tabular}{|c|c|c|c|c|c|c|c|}
\hline \multirow[t]{3}{*}{ Factor } & \multirow{3}{*}{$\begin{array}{l}\text { Variables } \\
\text { Little concern about } \\
\text { domestic recycling in } \\
\text { family }\end{array}$} & \multirow{2}{*}{$\begin{array}{l}\text { Respondent's } \\
\text { Type of Housing } \\
\text { Landed }\end{array}$} & \multirow{2}{*}{$\begin{array}{l}\text { Mean } \\
\text { Rank } \\
47.02\end{array}$} & \multirow{2}{*}{$\begin{array}{l}\begin{array}{c}z- \\
\text { value }\end{array} \\
-.787\end{array}$} & \multirow{2}{*}{$\begin{array}{c}{ }^{* *} \\
\mathrm{p} \text {-value } \\
.431\end{array}$} & \multicolumn{2}{|c|}{ Statistic } \\
\hline & & & & & & Mean & 2.92 \\
\hline & & High-rise & 42.61 & & & Mean & 2.74 \\
\hline & $\begin{array}{l}\text { Less information in } \\
\text { neighbourhood } \\
\text { community }\end{array}$ & Landed & 45.97 & -.244 & .807 & Mean & 2.51 \\
\hline & & High-rise & 44.61 & & & Mean & 2.42 \\
\hline \multirow{3}{*}{ Knowledge } & $\begin{array}{l}\text { Relatives and friends } \\
\text { rarely carry out }\end{array}$ & Landed & 46.18 & -.353 & .724 & Mean & 2.76 \\
\hline & $\begin{array}{l}\text { domestic waste } \\
\text { recycling }\end{array}$ & High-rise & 44.21 & & & Mean & 2.68 \\
\hline & $\begin{array}{l}\text { Authority did not } \\
\text { provide information }\end{array}$ & Landed & 43.48 & -1.054 & .292 & Mean & 2.29 \\
\hline
\end{tabular}




\begin{tabular}{|c|c|c|c|c|c|c|c|}
\hline & \multirow{3}{*}{$\begin{array}{l}\text { and recycling } \\
\text { program } \\
\text { Little concern about } \\
\text { environmental issues }\end{array}$} & High-rise & 49.34 & & & Mean & 2.48 \\
\hline & & Landed & 44.09 & -.729 & .466 & Mean & 2.37 \\
\hline & & High-rise & 48.18 & & & Mean & 2.55 \\
\hline \multirow{6}{*}{$\begin{array}{l}\text { Spatial and } \\
\text { Physical }\end{array}$} & Less provision of & Landed & 51.90 & \multirow{2}{*}{-3.405} & \multirow{2}{*}{.001} & Mean & 3.69 \\
\hline & $\begin{array}{l}\text { dustbin to each } \\
\text { house }\end{array}$ & High-rise & 33.32 & & & Mean & 2.87 \\
\hline & \multirow{2}{*}{$\begin{array}{l}\text { No access for } \\
\text { responsible } \\
\text { organisation to collect } \\
\text { recyclables }\end{array}$} & Landed & 49.94 & \multirow[t]{2}{*}{-2.298} & \multirow[t]{2}{*}{.022} & Mean & 3.32 \\
\hline & & High rise & 37.05 & & & Mean & 2.71 \\
\hline & \multirow[t]{2}{*}{$\begin{array}{l}\text { Narrow kerbside } \\
\text { space place dustbin }\end{array}$} & Landed & 46.08 & \multirow[t]{2}{*}{-.298} & \multirow{2}{*}{.766} & Mean & 3.31 \\
\hline & & High rise & 44.04 & & & Mean & 3.32 \\
\hline \multirow{12}{*}{ Situational } & \multirow{4}{*}{$\begin{array}{l}\text { Lack of sufficient } \\
\text { space storage } \\
\text { facilities to do } \\
\text { recycling } \\
\text { Lack of access to the } \\
\text { recycling facilities }\end{array}$} & Landed & 48.16 & \multirow[t]{2}{*}{-1.374} & \multirow[t]{2}{*}{.169} & Mean & 2.73 \\
\hline & & High rise & 40.44 & & & Mean & 2.29 \\
\hline & & Landed & 49.67 & \multirow{2}{*}{-2.168} & \multirow{2}{*}{.030} & Mean & 3.12 \\
\hline & & High rise & 37.56 & & & Mean & 2.55 \\
\hline & \multirow{2}{*}{$\begin{array}{l}\text { Frequent of recycling } \\
\text { collections only once } \\
\text { in a while }\end{array}$} & Landed & 45.25 & \multirow{2}{*}{-.130} & \multirow{2}{*}{.897} & Mean & 2.44 \\
\hline & & High rise & 45.97 & & & Mean & 2.45 \\
\hline & \multirow{2}{*}{$\begin{array}{l}\text { Recycling facilities } \\
\text { are not within an } \\
\text { appropriate location }\end{array}$} & Landed & 45.91 & & & Mean & 2.93 \\
\hline & & High rise & 44.73 & -.210 & .834 & Mean & 2.90 \\
\hline & Absence of recycling & Landed & 45.32 & & & Mean & 3.05 \\
\hline & 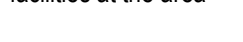 & High rise & 45.84 & $.00 \mathrm{~L}$ & & Mean & 3.10 \\
\hline & $\begin{array}{l}\text { No financial } \\
\text { incentives or rewards }\end{array}$ & Landed & 42.85 & 1.378 & .168 & Mean & 2.31 \\
\hline & are given to recycle & High rise & 50.55 & & & Mean & 2.71 \\
\hline & Responsible authority & Landed & 48.14 & -1.443 & .149 & Mean & 1.86 \\
\hline & $\begin{array}{l}\text { should run recycling } \\
\text { conveniently }\end{array}$ & High Rise & 40.48 & & & Mean & 1.61 \\
\hline & Recycling is & Landed & 47.14 & -.858 & .391 & Mean & 2.34 \\
\hline & $\begin{array}{l}\text { Wortinwhile onily } \\
\text { paid to do so }\end{array}$ & High Rise & 42.39 & & & Mean & 2.10 \\
\hline Attitude & Recycling only & Landed & 48.48 & -1.559 & .119 & Mean & 2.53 \\
\hline & $\begin{array}{l}\text { recycling business } \\
\text { only }\end{array}$ & High Rise & 39.82 & & & Mean & 2.13 \\
\hline & $\begin{array}{l}\text { Busy and do not have } \\
\text { time to recycle }\end{array}$ & Landed & 48.30 & -1.468 & .142 & Mean & 3.39 \\
\hline & & High Rise & 40.18 & & & Mean & 3.10 \\
\hline & Not willing to practice & Landed & 47.54 & -1.162 & .245 & Mean & 3.88 \\
\hline & recycling & High Rise & 41.61 & & & Mean & 3.65 \\
\hline & $\begin{array}{l}\text { Segregation } \\
\text { recyclable items }\end{array}$ & Landed & 45.30 & -.113 & .910 & Mean & 3.81 \\
\hline & $\begin{array}{l}\text { should be done by } \\
\text { garbage collector }\end{array}$ & High Rise & 45.89 & & & Mean & 3.77 \\
\hline & Recycling should be & Landed & 46.39 & -.465 & .642 & Mean & 3.20 \\
\hline & $\begin{array}{l}\text { one by individuals } \\
\text { and not the } \\
\text { community }\end{array}$ & High Rise & 43.81 & & & Mean & 3.03 \\
\hline & $\begin{array}{l}\text { Recycling is a } \\
\text { significant activity for }\end{array}$ & Landed & 43.84 & -.863 & .388 & Mean & 2.59 \\
\hline Social & folks who have time & High Rise & 48.66 & & & Mean & 2.81 \\
\hline & & Landed & 43.64 & -.985 & .325 & Mean & 2.03 \\
\hline
\end{tabular}




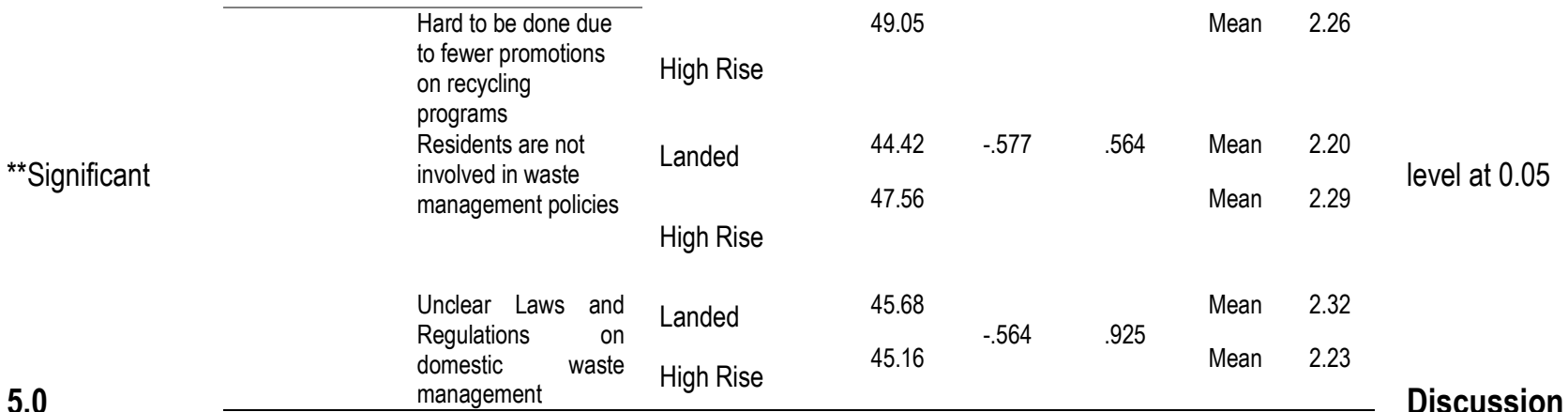

\subsection{Human Behaviours Characteristic of Domestic Waste Recycling}

The urban housing areas in Shah Alam consists of two (2) types which are landed and high rise property. Most apartment building only has recycling bins at the foot of the block or are located a distance away from established collection centres for recycling. Compared to landed property residents, this resulted in high-rise residents getting less access to recycling services. This findings supported by Jesson, Pocock, \& Stone, (2014), in apartment buildings, waste disposal systems raise a barrier to participation in recycling. Most unemployed responders had not many facing problems in doing recycling activities as compared to those who are working. This behaviour has been explained by the statement from Becker \& Lindhqvist, (2014) that recycling is among these environmental activities that are relatively easy to carry out, compared to other activities such as reducing car use, water or meat consumption. Recycling can hence be considered as an activity where one can easily contribute to society without high cost of time and effort. As unemployed (housewife and students) have more time available, this recycling activity presents a rewarding opportunity. Inactivity among this group was, however, reported as a discouraging factor that would defeat the argument of having more time available for recycling activities. It was mentioned that unemployed individuals present good knowledge on what and how to recycle. This could mean that this group particularly needs support in motivating this activity and less focus on education on recycling issues.

\subsection{Significant Difference in Domestic Waste Recycling Factors}

There were significance differences in perception on less provision of dustbin between respondents living in landed and high rise property. This is because most of the landed property in the study area has been provided with domestic waste bin (blue and orange coloured) in each of Zon Bersih neighbourhood. Satisfaction can be related to the factors associated with the quality of the service and quality of the product such as number of containers (Tabernero et al, 2015). Similarly, to perception of lack of access to domestic recycling facilities and access to collect domestic waste from responsible agencies. Majority of respondents living in landed property do not have much problem on the issue as they have easy access to recycling centre compared to those living in high rise property. This is supported by Rispo et al (2015), high dense households were expected to travel to recycling centres which are quite difficult to practice.

\subsection{Conclusion and Recommendations}

This preliminary study is intended to measure factors that contribute to human behaviours towards domestic waste recycling among urban household in Shah Alam before the actual survey is conducted. The study has its limitation where it focussed on domestic waste produced by households embeds among urban residents and site study within MBSA authority only which is Planning Block 1 . The sample size is also smaller which might affect the result of findings especially in analysing the significant differences between two (2) groups. The outcome of this study is expected to be used as fundamental data to carry along to the next level of the main research. Further research can be detailed up to measure on relationship between age, gender and educational level which also contributes to participation in recycling activities. This study has a considerable amount of benefits in meeting the government's need and encouraging the protection of human lives and environment. The study is significant as it is incorporate the household's role and responsibilities in assessing the local government to manage domestic waste.

\section{Acknowledgements}

The authors would like to express our gratitude to the Faculty of Architecture, Planning and Surveying, Universiti Teknologi MARA (UiTM); and the Ministry of Higher Education Malaysia through Fundamental Research Grant Scheme- RACER (600-IRMIS/FRGSRACER 5/3 (003/2019) for their generous contribution towards this research.

\section{Paper Contribution to Related Field of Study}

As the Malaysian Government had imposed its many initiatives to improve the impact of domestic waste disposal, this study initiated to respond to the global need of protecting the soil and water from pollution, as well as sustaining the resources. It is also to meet the government's strategy in "strengthening the enabling environment for green growth" through one of its initiative such as enhancing awareness to create shared responsibility. 


\section{References}

Abas, M. A. (2014). Municipal Solid Waste Management in Malaysia : An Insight Towards Sustainability. $4^{\text {th }}$ International Conference on Human Habitat and Environment 192 -206. https://doi.org/10.13140/2.1.1774.6246

Al Mamun, A., Mohiuddin, M., Ahmad, G. Bin, Thurasamy, R., \& Fazal, S. A. (2018). Recycling intention and behavior among low-income households. Sustainability (Switzerland), 10(7), 1-22. https://doi.org/10.3390/su10072407

Becker, N., \& Lindhqvist, T. (2014). Increasing High Recycling Rates. Sociodemographics as an additional layer of information to improve waste management. Master Thesis. Lund University, Sweden. https://doi.org/10.13140/RG.2.2.29133.33769

Chu, P. Y., \& Chiu, J. F. (2003). Factors influencing household waste recycling behavior: Test of an integrated model. Journal of Applied Social Psychology, 33(3), 604626. https://doi.org/10.1111/j.1559-1816.2003.tb01915.x

Jesson, J. K., Pocock, R., \& Stone, I. (2014). Barriers to recycling: A review of evidence since 2008 M-E-L Research A Report for WRAP. (December 2014$), 2008-2013$. Retrieved from www.wrap.org.uk

Knickmeyer, D. (2020). Social factors influencing household waste separation: A literature review on good practices to improve the recycling performance of urban areas. Journal of Cleaner Production, 245, 118605. https://doi.org/10.1016/j.jclepro.2019.118605

Kumar, A. (2019). Exploring young adults' e-waste recycling behaviour using an extended theory of planned behaviour model: A cross-cultural study. Resources, Conservation and Recycling, 141(June 2018), 378-389. https://doi.org/10.1016/j.resconrec.2018.10.013

Miafodzyeva, S. (2012). Understanding the Recycling Behaviour of Householders in Multicultural Urban Areas: Case Study Järva, Stockholm. Retrieved from https://www.diva-portal.org/smash/get/diva2:556893/FULLTEXT01.pdf

Miliute-Plepiene, J., Hage, O., Plepys, A., \& Reipas, A. (2016). What motivates households recycling behaviour in recycling schemes of different maturity? Lessons from Lithuania and Sweden. Resources, Conservation and Recycling, 113, 40-52. https://doi.org/10.1016/j.resconrec.2016.05.008

Ong, C., Fearnley, L., \& Chia, S. B. (2019). Towards a sustainable future: a holistic inquiry of waste management behaviors of Singapore households. International Journal of Sustainable Development and World Ecology, 26(7), 583-596. https://doi.org/10.1080/13504509.2019.1631898

Othman, A. R., \& Yuhaniz, M. (2012). Recycle of Domestic Waste among Terrace House Residents in Shah Alam. Procedia - Social and Behavioral Sciences, 50(July), 884-898. https://doi.org/10.1016/j.sbspro.2012.08.090

Shahol Hamid, F., \& Agamuthu, P. (2012). Trends in sustainable landfilling in Malaysia, a developing country. Waste Management and Research, 30(7), 656-663. https://doi.org/10.1177/0734242X12437564

Strydom, W. F. (2018). Applying the theory of planned behavior to recycling behavior in South Africa. Recycling, 3(3). https://doi.org/10.3390/recycling3030043

Thomas, C., \& Sharp, V. (2013). Understanding the normalisation of recycling behaviour and its implications for other pro-environmental behaviours: A review of social norms and recycling. Resources, Conservation and Recycling, 79, 11-20. https://doi.org/10.1016/j.resconrec.2013.04.010

Umar, S., Sehab, P., \& Yagnik, P. (2018). 3R's Concept : Reduce, Reuse \& Recycle Sardar Patel College of Engineering, Anand, India. International Journal for Scientific Research \& Development, 6(03), 57-59.

Wang, B., Ren, C., Dong, X., Zhang, B., \& Wang, Z. (2019). Determinants shaping willingness towards on-line recycling behaviour: An empirical study of household ewaste recycling in China. Resources, Conservation and Recycling, 143(January 2019), 218-225. https://doi.org/10.1016/j.resconrec.2019.01.005

$\mathrm{Xu}$, L., Ling, M., Lu, Y., \& Shen, M. (2017). Understanding household waste separation behaviour: Testing the roles of moral, past experience, and perceived policy effectiveness within the theory of planned behaviour. Sustainability (Switzerland), 9(4). https://doi.org/10.3390/su9040625

Zen, I. S., Noor, Z. Z., \& Yusuf, R. O. (2014). The profiles of household solid waste recyclers and non-recyclers in Kuala Lumpur, Malaysia. Habitat International, 42, 8389. https://doi.org/10.1016/j.habitatint.2013.10.010 